\title{
Effect of cadmium on the susceptibility of Tubifex tubifex to Myxobolus cerebralis (Myxozoa), the causative agent of whirling disease
}

\author{
Sho Shirakashi ${ }^{1}$, Mansour El-Matbouli ${ }^{2, *}$ \\ ${ }^{1}$ Clinic for Fish and Reptiles, Faculty of Veterinary Medicine, University of Munich, Munich, Germany \\ ${ }^{2}$ Fish Medicine and Livestock Management, Department for Farm Animals and Veterinary Public Health, \\ University of Veterinary Medicine, Veterinaerplatz 1, 1210 Vienna, Austria
}

\begin{abstract}
Environmental pollutants alter a wide range of host-parasite interactions in various ways. In some cases, pollution leads to a significant increase in parasite abundance, causing epidemics of parasitic diseases. In other cases, toxicants restrict the transmission success of parasites, resulting in reduction of their abundance. However, very little is known regarding whether and to what extent aquatic pollution affects myxozoan obligate parasites commonly found in fish. We investigated the effect of cadmium (Cd) on the aquatic oligochaete Tubifex tubifex infected with the myxozoan Myxobolus cerebralis. The oligochaetes were experimentally exposed to M. cerebralis myxospores and kept in various concentrations of $\mathrm{Cd}$ for 4 mo. Neither survival nor reproduction of the worms was affected by the metal, but infection prevalence and numbers of triactinosmyxon spores produced by individual worms were higher in the Cd-exposed group than the unexposed control. A comparative assay of a lethal $\mathrm{Cd}$ concentration $\left(\mathrm{LC}_{50}\right)$ on infected and non-infected $T$. tubifex revealed that infected worms are more resistant to the acute toxicity of $\mathrm{Cd}$, probably because uptake of $\mathrm{Cd}$ was reduced by the infection. These results suggest that the abundance of $M$. cerebralis likely increases in polluted waters and escalates the risk of whirling disease in the respective area.
\end{abstract}

KEY WORDS: Myxozoa - Tubificid - Whirling disease $\cdot$ Pollution $\cdot \mathrm{LC}_{50} \cdot$ Cadmium $\cdot$ Toxicity · Autotomy

Resale or republication not permitted without written consent of the publisher

\section{INTRODUCTION}

Complex host-parasite interactions are often greatly altered by human activities. Translocation of live animals and destruction of environments are just a few such activities altering parasite communities which may lead to outbreaks of emerging diseases (Patz et al. 2000). In the aquatic environment, pollution has a significant impact on host-parasite associations (Khan \& Thulin 1991, Poulin 1992, Williams \& MacKenzie 2003, Sures 2008). Metals, pesticides, sewage effluents and other pollutants directly affect ectoparasites and freeliving stages as well as indirectly influence endoparasites through interference with the hosts' physiological homeostasis or immune defense (Khan \& Thulin 1991). Pollutants may also alter food web structure and the abundance of intermediate hosts, resulting in significant changes in the transmission dynamics of parasites (Lafferty 2008).

Alterations of parasitic diversity and abundance associated with aquatic pollution have been documented in various field and laboratory studies. For example, the intensity and diversity of parasites on the Spanish marine fish Boops boops significantly increased shortly after an oil spill (Perez-Del-Olmo et al. 2009); parasite species richness in freshwater fishes has been positively associated with eutrophication in Finnish lakes (Valtonen et al. 1997); and Coors et al. (2008) experi- 
mentally demonstrated that pesticides increase the virulence of a bacterium and microsporidium for their crustacean host, Daphnia magna. The abundance of ectoparasites and protozoans are generally positively correlated, to some extent, with the degree of pollution (MacKenzie et al. 1995, MacKenzie 1999, Khan 2003), while numbers of endoparasitic helminths tend to decline under polluted conditions (Poulin 1992, Marcogliese \& Cone 1997, MacKenzie 1999, Marcogliese 2005). An increment in ectoparasites and protozoans likely attributed to impaired immune response of the host and the reduction of endoparasitic helminths may be due to toxic effects on intermediate hosts or freeliving stages. Despite the accumulating knowledge on the effects of environmental pollution on host-parasite systems, very little is known regarding whether pollution affects infection dynamics of myxozoans, obligate heteroxenous endoparasites.

Nearly all myxozoans are found in the aquatic environment (Canning \& Okamura 2003, Lom \& Dykova 2006, Bartholomew et al. 2008), though some infect terrestrial mammals (Prunescu et al. 2007). Therefore, their transmission, development and propagation are directly affected by aquatic pollution. In the present study, we used the Myxobolus cerebralis-Tubifex tubifex system to investigate the effects of a metal toxicant on myxozoan infection. The parasite, M. cerebralis, is the most well-studied myxozoan as it causes the notorious salmonid whirling disease that has been causing tremendous losses in wild and cultured trout populations in North America (Nehring \& Walker 1996, Bartholomew \& Reno 2002).

The life cycle of Myxobolus cerebralis involves 2 alternate hosts: salmonid fish and the cosmopolitan freshwater oligochaete Tubifex tubifex (Markiw \& Wolf 1983, Wolf et al. 1986). Following ingestion by the oligochaete, the parasite undergoes development and propagation between the gut epithelial cells (El-Matbouli \& Hoffmann 1998). Within several months, numerous triactinomyxon spores (TAMs) are released into the water and subsequently infect the suitable fish host (El-Matbouli et al. 1999, Gilbert \& Granath 2001, Stevens et al. 2001). Infection in T. tubifex may persist for the duration of the worm's lifespan and release of TAMs can occur periodically over the span of at least a few years (Gilbert \& Granath 2001). Infected worms suffer from suppressed feeding, reduced growth (Stevens et al. 2001, Kerans et al. 2004, Steinbach Elwell et al. 2006, Rasmussen et al. 2008) and inhibited reproductive development (Shirakashi \& El-Matbouli 2009), though no obvious parasite effects on survival have been shown (Shirakashi \& El-Matbouli 2009). Several studies have revealed the importance of environmental factors such as temperature and substrate (Kerans \& Zale 2002) and water flow (Hallett \&
Bartholomew 2008) on the establishment and development of the parasite within T. tubifex.

Tubifex tubifex is highly tolerant to polluted environments. Understanding the relationship between $T$. tubifex and Myxobolus cerebralis under polluted conditions may be important for predicting outbreaks of whirling disease. However, T. tubifex is highly polymorphic and its susceptibility to pollutants and the parasite is highly variable. To date, 6 mitochondrial lineages (I to VI) of T. tubifex have been distinguished (Beauchamp et al. 2001, Sturmbauer et al. 1999), and only lineages I (in some cases) and III are susceptible to M. cerebralis (Beauchamp et al. 2002, 2005, 2006, DuBey et al. 2005). Moreover, tolerance against pollutants differs between the lineages (Sturmbauer et al. 1999). In the present study, we used a monoculture of lineage III $T$. tubifex to investigate whether cadmium (Cd) affects its susceptibility to $M$. cerebralis and if its tolerance against the metal is influenced by infection with the parasite.

\section{MATERIALS AND METHODS}

Study species. Tubifex tubifex were originally collected from a sewage pond in Aufseß (Bavaria, Germany) and had been maintained in the laboratory for over 2 yr. The stock culture consisted of various oligochaete species including T. tubifex lineages II and III, thus a subculture of the susceptible T. tubifex was initiated. The mixed culture of worms was experimentally exposed to Myxobolus cerebralis myxospores and individuals confirmed to release TAMs were selected. Because infected $T$. tubifex are reproductively impaired (Shirakashi \& El-Matbouli 2009), they were first kept at $28 \pm 2{ }^{\circ} \mathrm{C}$ to overcome the infection (El-Matbouli et al. 1999). Monoculture of the susceptible strain was started using cocoons produced by these worms. Based on the molecular analyses on sampled worms, the culture was identified as mitochondrial lineage III, which is relatively insensitive to $\mathrm{Cd}$ according to Sturmbauer et al. (1999). To avoid contamination by pollutants in the natural sediment, an artificial substrate consisting of quartz sand (<250 um) and Kaolinite clay (approximately 8:2 in volume) was used. The culture was held in an 841 plastic container with flow-through water at $15 \pm 2{ }^{\circ} \mathrm{C}$. A mixture of Tetramin flake fish food, algae pellets and dried artemia was given weekly.

Myxospores of Myxobolus cerebralis were obtained from experimentally infected juvenile rainbow trout that were raised from eggs under specific pathogenfree (SPF) conditions. The myxospores were collected by homogenising head and skeletal tissue of 5 fish showing typical symptoms of whirling disease. The spores were counted using a haemocytometer. 
Long-term Cd exposure experiment. Effects of $\mathrm{Cd}$ on the susceptibility of Tubifex tubifex to Myxobolus cerebralis were assessed by infecting worms in various concentrations of $\mathrm{Cd}$. Solutions of $0,0.01,0.1,1.0$ and $2.0 \mathrm{mg} \mathrm{l}^{-1}$ were prepared with $\mathrm{CdCl}_{2} \cdot 2 / 5 \mathrm{H}_{2} \mathrm{O}$ and tap water. The worms were assigned to one of the concentrations in a plastic container $(8 \mathrm{~cm}$ diameter, $9 \mathrm{~cm}$ depth) with $50 \mathrm{ml}$ quartz sand and $150 \mathrm{ml}$ solution. Four replicate containers were prepared for each concentration. Worms were first acclimated to the experimental conditions for $1 \mathrm{wk}$ without food and then 50000 myxospores were added (1000 spores per individual). Slight aeration was provided and $1 \mathrm{ml}$ of food was given every week. To avoid loss of myxospores, Cd solutions were renewed twice during the experiment at 1 and 2 mo post exposure. After 3 mo, TAM production was checked every 2 wk and the experiment was terminated at $15 \mathrm{wk}, 2 \mathrm{wk}$ after the first TAM detection.

At the end of the experiment, the substrate was sieved to count survivors, offspring and cocoons in each container. The survivors were placed individually in the wells of 48 well microtiter plates with $1 \mathrm{ml}$ water and the proportion of autotomised individuals, infection prevalence and number of TAMs produced within $48 \mathrm{~h}$ were determined. Worms with a missing or apparently regenerated (abnormally short) caudal body part were considered 'autotomised'. The total number of TAMs produced by individuals was calculated from the average spore count in 2 sets of $10 \mu \mathrm{l}$ from $1 \mathrm{ml}$ solution in each well.

$\mathbf{L C}_{50}$ toxicity test. The effects of Myxobolus cerebralis on the sensitivity of Tubifex tubifex to acute cadmium toxicity were investigated. The mortality of infected and uninfected worms in various concentrations of $\mathrm{Cd}$ was assessed and the lethal concentrations $\left(\mathrm{LC}_{50}\right)$ were calculated. Both groups of worms were originally from the same culture, but the infected group was experimentally exposed to fish homogenate containing myxospores. The controls were exposed to the same amount of tissue homogenate from uninfected SPF fish. The worms were maintained under the same conditions for approximately $4 \mathrm{mo}$ and were individually checked for infection in a 48 well microtiter plate. All infected individuals were releasing TAMs at the time of the experiment and controls were free of the parasite.

The $96 \mathrm{~h} \mathrm{LC}_{50}$ bioassay was conducted using Cd concentrations of $0,0.01,0.03,0.05,0.07$ and $0.10 \mathrm{mg} \mathrm{l}^{-1}$ $\left(\mathrm{CdCl}_{2} \cdot 2 / 5 \mathrm{H}_{2} \mathrm{O}\right.$ in distilled $\left.\mathrm{H}_{2} \mathrm{O}\right)$. The preliminary trial showed that worms can survive in distilled $\mathrm{H}_{2} \mathrm{O}$ for 1 wk. For each concentration, 10 infected and 10 control worms were individually placed in a 24 well microtiter plate with $1 \mathrm{ml}$ solution and kept at $20 \pm 2^{\circ} \mathrm{C}$ under ambient light. The solutions were replaced every $24 \mathrm{~h}$ with freshly prepared ones and no food was given dur- ing the experiment. Numbers of dead individuals were noted every $24 \mathrm{~h}$ until the experiment was terminated at $96 \mathrm{~h}$. Worms were considered dead if they showed no sign of movement and more than $90 \%$ of the body was degenerated. The entire experiment was repeated 4 times.

Statistical analyses. The data were tested for normality and homogeneity of variance using the Shapiro-Wilks and Bartlett's tests. ANOVA was used for comparison of the survival rate between different $\mathrm{Cd}$ concentrations in the long-term experiment. The infection prevalence of Cd-treated groups and control groups was compared using Dunnett's multiple comparison test. The effects of $\mathrm{Cd}$ on TAM production was tested using the Kruskal-Wallis test followed by Steel's nonparametric multiple comparison test. In the toxicity test, the average survival rate between uninfected and infected Tubifex tubifex in each Cd concentration was compared using Kaplan-Meier survival analysis. Mortality at 72 and $96 \mathrm{~h}$ was subjected to probit analysis to obtain the $\mathrm{LC}_{50}$. These analyses were performed using JMP, StatPlus and Kyplot statistical software.

\section{RESULTS}

\section{Long-term Cd exposure}

The metal affected neither survival nor reproduction of the oligochaetes, but some effects on susceptibility to the parasite were observed. The overall average survival rate was $79.3 \pm 14.2 \%$ and the survival was not significantly different between groups (ranged from $70.5 \pm 21.44 \%$ in $0.01 \mathrm{mg} \mathrm{l}^{-1}$ to $83.0 \pm 17.01 \%$ in $1.0 \mathrm{mg}$ $\mathrm{l}^{-1}$ ). The mean infection prevalence exceeded $60 \%$ in all groups. The control showed the lowest prevalence and the highest prevalence was observed in the $1.0 \mathrm{mg}$ $\mathrm{l}^{-1}$ group (Fig. 1). However, the difference between treatment group and control was not statistically significant (Dunnett's test, $\mathrm{p}>0.05$ ). The average numbers of produced TAMs differed significantly between groups (Kruskal-Wallis, $\mathrm{p}<0.0001$; Fig. 2). All the Cdexposed groups produced significantly greater numbers of spores than the unexposed control (Steel's test: $0.01 \mathrm{mg} \mathrm{l}^{-1}, t=-7.19, \mathrm{p}<0.01 ; 0.1 \mathrm{mg} \mathrm{l}^{-1}, t=-3.93, \mathrm{p}<$ $0.01 ; 1.0 \mathrm{mg} \mathrm{l}^{-1}, t=-7.19, \mathrm{p}<0.01 ; 2.0 \mathrm{mg} \mathrm{l}^{-1}, t=-4.63$, $\mathrm{p}<0.01$ ). The oligochaetes exposed to Cd showed a lower autotomy rate than the control (Fig. 3). Most autotomised worms possessed a regenerated posterior end, indicating that autotomisation occurred relatively early in the experiment. The numbers of offspring varied considerably among replicates, ranging from 2 to 428 , and there were no significant differences between treatment groups. 


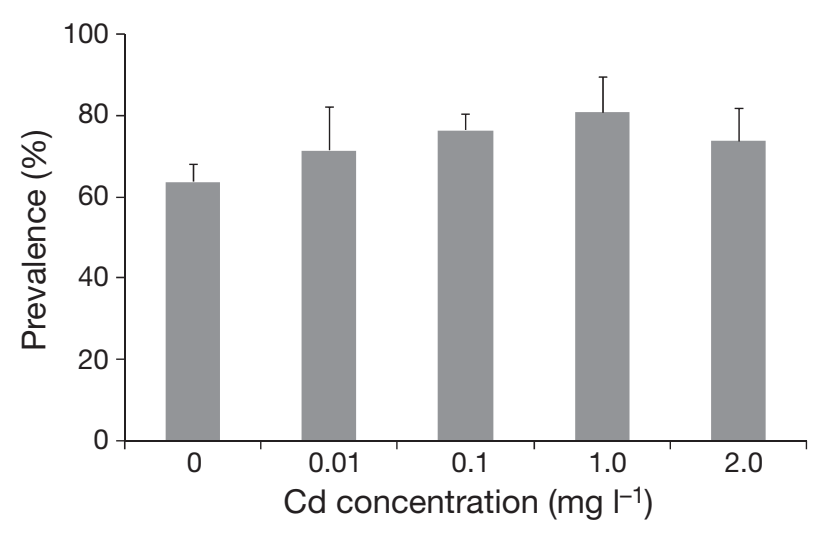

Fig. 1. Tubifex tubifex. Mean (+SE) Myxobolus cerebralis infection prevalence of $T$. tubifex exposed to various concentrations of cadmium

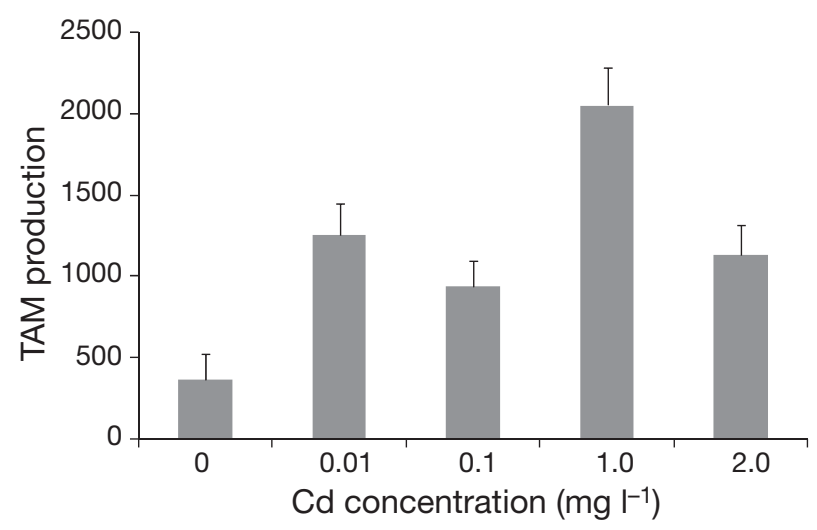

Fig. 2. Myxobolus cerebralis and Tubifex tubifex. Mean (+SE) numbers of $M$. cerebralis triactinomyxon spores (TAMs) produced by individual $T$. tubifex exposed to various concentrations of cadmium

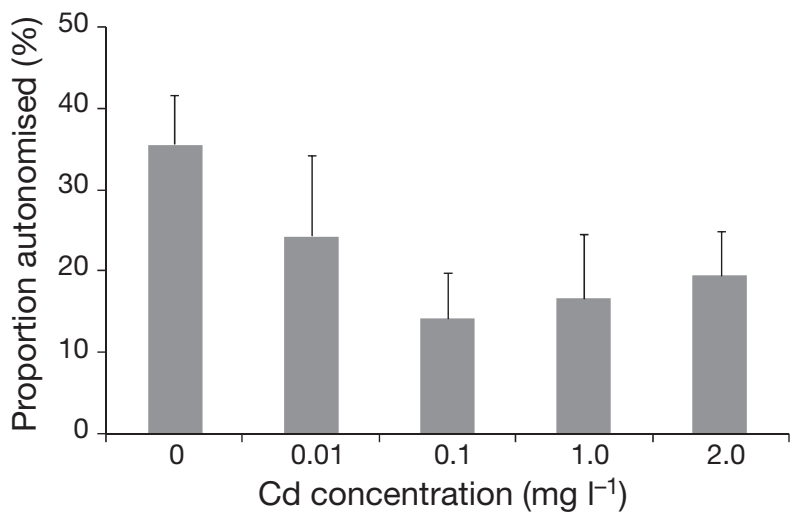

Fig. 3. Tubifex tubifex. Mean (+SE) autotomy rate of T. tubifex exposed to various concentrations of cadmium

\section{$\mathrm{LC}_{50}$ toxicity}

The toxicity assay showed that uninfected Tubifex tubifex were more susceptible to $\mathrm{Cd}$ than those infected by Myxobolus cerebralis. Kaplan-Meier analysis revealed that the survival of the uninfected controls was significantly lower than that of the infected groups for $\mathrm{Cd}$ concentrations of $0.05(\mathrm{p}=$ $0.0128), 0.07(\mathrm{p}=0.0295)$ and $0.10 \mathrm{mg} \mathrm{l}^{-1}(\mathrm{p}=0.0124$; Fig. 4). A similar difference was not observed in groups with lower Cd concentrations (0.01 and $0.03 \mathrm{mg} \mathrm{l}^{-1}, \mathrm{p}>$ 0.1 and no mortality was observed in the control group $\left(0 \mathrm{mg} \mathrm{l}^{-1}\right)$. The mean $\mathrm{LC}_{50}$ values of 4 assay trials were nearly 4- or 2-fold lower for uninfected oligochaetes at $72 \mathrm{~h}$ and $96 \mathrm{~h}$, respectively (mean $\mathrm{LC}_{50} \pm \mathrm{SD}, 95 \%$ mean CI, $72 \mathrm{~h}$ : control, $0.05 \pm 0.04 \mathrm{mg} \mathrm{l}^{-1}, 0.03$ to $11.6 \mathrm{mg} \mathrm{l}^{-1}$; infected, $0.21 \pm 0.21 \mathrm{mg} \mathrm{l}^{-1} 0.02$ to $14.03 \mathrm{mg}$ $\mathrm{l}^{-1} ; 96 \mathrm{~h}$ : control, $0.03 \pm 0.02 \mathrm{mg} \mathrm{l}^{-1}, 0.01$ to $0.11 \mathrm{mg} \mathrm{l}^{-1}$; infected, $0.05 \pm 0.04 \mathrm{mg} \mathrm{l}^{-1}, 0.02$ to $5.31 \mathrm{mg} \mathrm{l}^{-1}$ ). However, no statistical significance between the 2 groups was detected for either time point ( $t$-test: $72 \mathrm{~h}: t=1.44$, $\mathrm{p}=0.20 ; 96 \mathrm{~h}: t=0.80, \mathrm{p}=0.46)$.

\section{DISCUSSION}

Increased parasite abundance and incidence of parasitic disease associated with pollution have been documented mostly for protozoan and monogenean parasites (MacKenzie et al. 1995, MacKenzie 1999). For instance, chemical pollutants increased the susceptibility of eastern oyster to the protozoa Perkinsus marinus, the causative agent of the dermo disease responsible for high mortalities of oyster on American coasts (Chu et al. 2002). On the other hand, pollutants seem to have negative effects on endoparasitic helminths, and their abundance tends to be lower in polluted conditions (Poulin 1992, Marcogliese \& Cone 1997, MacKenzie 1999, Marcogliese 2005).

In the present study, infection prevalence did not differ between the Cd-treated and Cd-free groups, although the Cd-treated worms produced greater numbers of TAMs. The lack of apparent difference in infection prevalence suggests that $\mathrm{Cd}$ has no clear effect on the susceptibility of Tubifex tubifex to Myxobolus cerebralis. However, because the experiment was terminated at $15 \mathrm{wk}_{\text {, just after the worms }}$ started to produce spores, the long-term effect of $\mathrm{Cd}$ on the host-parasite interaction is still unknown. Also, use of the molecular method for determination of infection and an an increased number of replicates may yield different results.

The greater TAM production of Cd-exposed Tubifex tubifex suggests that the metal facilitated development of Myxobolus cerebralis in its invertebrate host. 
Although the mechanism behind this phenomenon is unknown, Cd may alter immunological processes of the worm. Immunotoxicological effects of $\mathrm{Cd}$ have been reported in various aquatic animals. In fish, $\mathrm{Cd}$ reduced numbers of white blood cells and induced blood cell deformation (Witeska et al. 2006) and lymphocyte mortality (Witeska \& Wakulska 2007), leading to higher intensities of monogenean and protozoan parasites (Hoole 1997, Khan 2003, Sanchez-Ramirez et al. 2007). Similarly, short-term exposure to high concentrations of $\mathrm{Cd}$ significantly increased the encystment of a trematode parasite Echinoparyphium recurvatum in its first intermediate host, the snail Lymnaea peregra (Morley et al. 2004). In oligochaetes, exposure to metals reduced coelomocytes and increased abundance of coelomic bacteria in Dendrobaena veneta (Wieczorek-Olchawa et al. 2003). Such Cd-induced reduction in coelom defense may also occur in $T$. tubifex and it may facilitate the development of $M$. cerebralis. However, more immunological and physiological studies are required to determine the precise mechanism behind the reduced resistance of metalexposed worms to the parasite.

Possible links between pollution and myxozoan diseases in fishes have been documented in field studies. Cone et al. (1997) reported an unusually high intensity of Myxobolus procerus in trout-perch Percopsis omiscomaycus from a highly polluted area of Lake Superior, USA. Nases Chondrostoma nasus from a copper- polluted river in Australia were more heavily infected with Myxobolus muelleri compared to the fish from less polluted waters (Jirsa et al. 2008). El-Matbouli \& Hoffmann (2002) indicated a strong association between organic pollutants and the occurrence of proliferative kidney disease in trout, which is caused by the myxozoan Tetracapsula bryosalmonae. Modin (1988) also reported a serious whirling disease outbreak in a trout hatchery which used contaminated water. In most of these cases, high myxozoan infection in the vertebrate hosts was associated with greater abundance of invertebrate hosts (oligochaetes for $M$. procerus and bryozoans for T. bryosalmonae) in their favourable eutrophied environment. However, as indicated in the present study, pollutants may also increase spore production of the invertebrate hosts, and this could be an important additive factor in epidemics of myxozoan diseases in fish hosts.

Metals have both lethal and sublethal effects on Tubifex tubifex. The latter include reduction in growth (Milani et al. 2003), reproduction (Gillis et al. 2002) and hormonal activity (Chen et al. 1994) and an increase in mucus production (Bouché et al. 2000) and autotomy (Brković-Popović \& Popović 1977, Lucan-Bouché et al. 1999, Bouché et al. 2000). Autotomy followed by regeneration of a broken caudal body part is commonly observed in oligochaetes suffering from various stressors such as predation and toxicant exposure. Bouché et al. (2000) suggested that autotomy is a

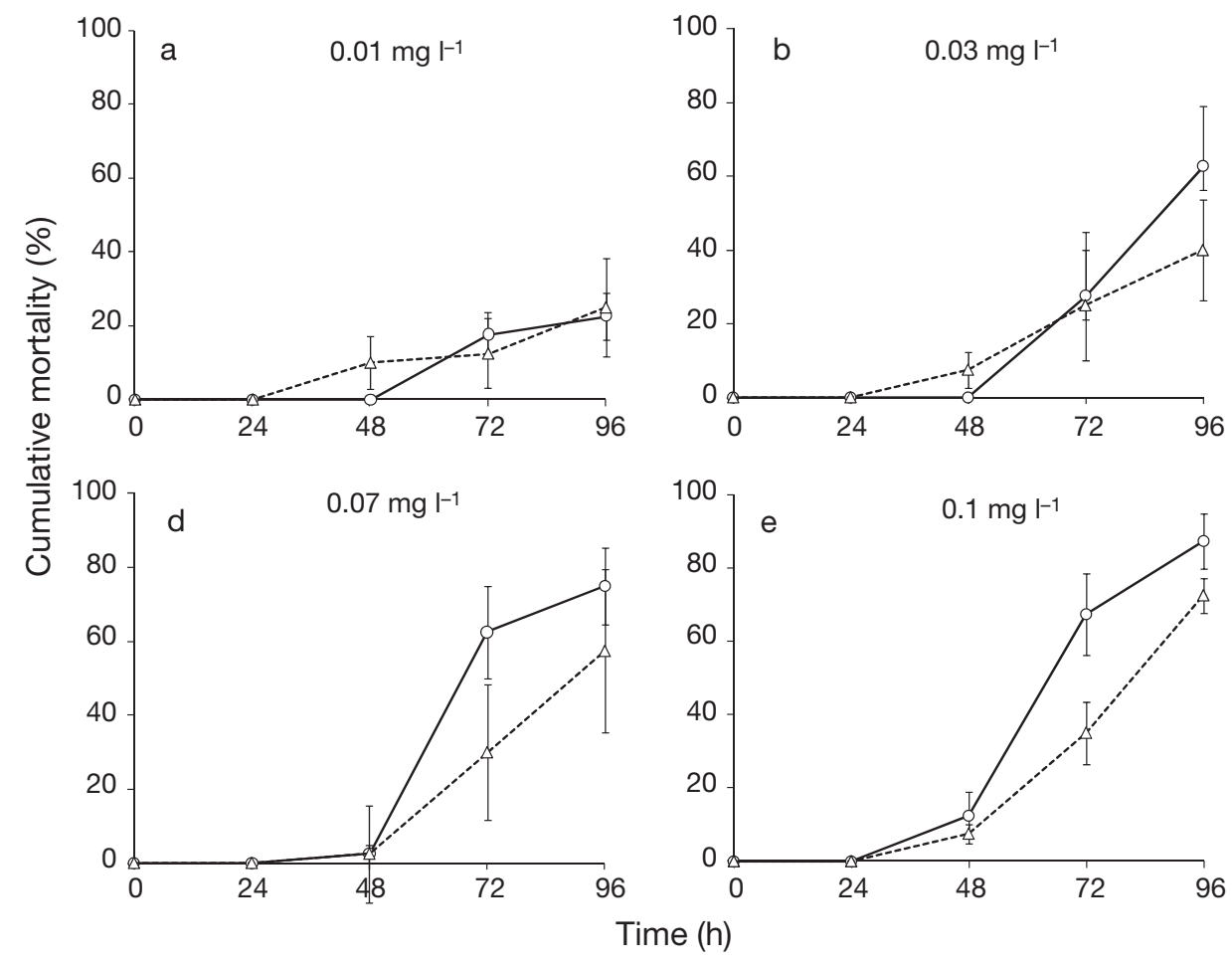

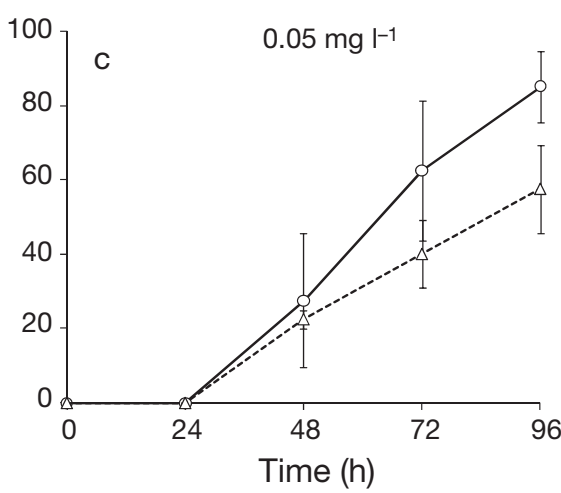

Fig. 4. Tubifex tubifex. Mean $( \pm \mathrm{SE})$ cumulative mortality of uninfected (solid line) and Myxobolus cerebralis-infected (dashed line) $T$. tubifex exposed to (a) 0.01, (b) 0.03, (c) 0.05 , (d) 0.07 and (e) $0.1 \mathrm{mg} \mathrm{l}^{-1}$ cadmium concentrations 
detoxication process in which the caudal body accumulating toxicants is dislodged from the body. In the present study, the autotomy rate was much lower for the Cd-exposed worms, and this apparently contradicts other reports. There are 3 possible explanations for this phenomenon: (1) autotomy in Cd-exposed worms occurred in a very early toxification period and the regeneration of the missing body part was completed by the end of the experiment (the regeneration rate of the autotomised caudal part can be as fast as $160 \mu \mathrm{m} \mathrm{d}^{-1}$; Bouché et al. 2003); (2) Cd reduced the worms' burrowing activity in the artificial substrate, which could damage their caudal part; and (3) Мухоbolus cerebralis infection also induced autotomy, but the process was interfered with by Cd. Regardless of the metal exposure, the rate of autotomy seemed to be higher in infected worms than uninfected ones (S. Shirakashi pers. obs.). This suggests that autotomy may also be a possible defence mechanism against parasites. However, more studies are needed to deepen our understanding of this phenomenon.

The acute lethality tests showed a negative association between infection and the lethal effect of $\mathrm{Cd}$. The $\mathrm{LC}_{50}$ values observed in the present study were comparable with Bouché et al.'s (2000) results, and slightly lower than those of Sturmbauer et al. (1999), though the results of past studies were highly variable. The apparently higher toxicity of $\mathrm{Cd}$ in acute lethality tests compared to the long-term exposure experiment likely arose from the different amounts of available $\mathrm{Cd}$ in the water: in the long-term experiment, Cd was adsorbed to the organic and inorganic materials in the container and its toxicity was greatly reduced, whereas more $\mathrm{Cd}$ was available in the assay trial because the solutions were replaced every $24 \mathrm{~h}$. The higher LC $_{50}$ values of infected worms and thus their higher resistance to $\mathrm{Cd}$ were unexpected because Myxobolus cerebralis infections would cause adverse physiological changes in the worm. The simplest interpretation of the observed results is that Cd uptake was affected by the infection. M. cerebralis reduces food intake of Tubifex tubifex by 40\% (Shirakashi \& El-Matbouli 2009). Although no substrate was provided in the assay, TAM-releasing worms likely had lower $\mathrm{Cd}$ uptake rates compared to the uninfected control. Another explanation is that the toxicity of $\mathrm{Cd}$ was reduced by the parasite. Some parasites, mainly acanthocephalans and cestodes, are known to accumulate toxicants at considerably higher rates than the hosts. These parasites act as detoxificants and reduce the amount of toxic substances in the host tissue (Sures 2008). Whether myxozoans accumulate metals at such a high rate is unclear, and an experiment using the worms at earlier infection stages may provide a different result. Nevertheless, there is the possibility that $T$. tubifex infected with $M$. cerebralis have higher $\mathrm{Cd}$ tolerance in polluted environments and are selected for in such conditions.

In conclusion, the present study indicated the possible association between aquatic pollution and the epidemic of myxozoan diseases in fishes. Pollutants can induce greater actinospore production and may increase the abundance of susceptible oligochaetes through the induction of mortality of uninfected worms. We strongly emphasise that pollution control is important not only for environmental health but also for preventing the spread of whirling disease in wild and cultured trout populations.

Acknowledgements. This study was funded by the Alexander von Humboldt-Stiftung to S.S. We thank S. Ihmels for assisting with the initiation of the worm culture. Thanks also to D. Grabner, D. Kallert and R. Kinami for their comments on an earlier version of the manuscript.

\section{LITERATURE CITED}

Bartholomew JL, Reno PW (2002) The history and dissemination of whirling disease. In: Bartholomew JL, Wilson JC (eds) Whirling disease: reviews and current topics. Am Fish Soc Symp 29:3-24

Bartholomew JL, Atkinson SD, Hallett SL, Lowenstine LJ and others (2008) Myxozoan parasitism in waterfowl. Int J Parasitol 38:1199-1207

Beauchamp KA, Kathman RD, McDowell TS, Hedrick RP (2001) Molecular phylogeny of tubificid oligochaetes with special emphasis on Tubifex tubifex (Tubificidae). Mol Phylogenet Evol 19:216-224

Beauchamp KA, Gay M, Kelley GO, El-Matbouli M, Kathman RD, Nehring RB, Hedrick RP (2002) Prevalence and susceptibility of infection to Myxobolus cerebralis, and genetic differences among populations of Tubifex tubifex. Dis Aquat Org 51:113-121

Beauchamp KA, Kelley GO, Nehring RB, Hedrick RP (2005) The severity of whirling disease among wild trout corresponds to the differences in genetic composition of Tubifex tubifex populations in central Colorado. J Parasitol 91:53-60

Beauchamp KA, El-Matbouli M, Gay M, Georgiadis MP, Nehring RB, Hedrick RP (2006) The effect of cohabitation of Tubifex tubifex (Oligochaeta: Tubificidae) populations on infections to Myxobolus cerebralis (Myxozoa: Myxobolidae). J Invertebr Pathol 91:1-8

Bouché ML, Habets F, Biagianti-Risbourg S, Vernet G (2000) Toxic effects and bioaccumulation of cadmium in the aquatic oligochaete Tubifex tubifex. Ecotoxicol Environ Saf 46:246-251

Bouché ML, Arnoult F, Vernet G (2003) Caudal regeneration in Tubifex tubifex (Oligochaeta, Tubificidae) following copper exposure. Invertebr Biol 122:42-51

> Brkoviç-Popoviç I, Popoviç M (1977) Effects of metals on survival and respiration rate of tubificid worms. Part I: effects on survival. Environ Pollut 13:65-72

Canning EU, Okamura B (2003) Biodiversity and evolution of the Myxozoa. Adv Parasitol 56:43-131

Chen T, Furst A, Chien PK (1994) The effects of cadmium and iron on catalase activities in Tubifex. J Am Coll Toxicol 13: $112-120$

Chu FLE, Volety AK, Hale RC, Huang YQ (2002) Cellular 
responses and disease expression in oysters (Crassostrea virginica) exposed to suspended field-contaminated sediments. Mar Environ Res 53:17-35

> Cone D, Eurell T, Axler R, Rau D, Beasley V (1997) Intense infections with a variant of Myxobolus procerus (Myxosporea) in muscle of trout-perch (Percopsis omiscomaycus) in Duluth Harbor, Lake Superior. Folia Parasitol 44:7-11

Coors A, Decaestecker E, Jansen M, De Meester L (2008) Pesticide exposure strongly enhances parasite virulence in an invertebrate host model. Oikos 117:1840-1846

> DuBey R, Caldwell C, Gould WR (2005) Effects of temperature, photoperiod, and Myxobolus cerebralis infection on growth, reproduction, and survival of Tubifex tubifex lineages. J Aquat Anim Health 17:338-344

Eiras JC (2005) An overview on the myxosporean parasites in amphibians and reptiles. Acta Parasitol 50:267-275

El-Matbouli M, Hoffmann RW (1998) Light and electron microscopic studies on the chronological development of Myxobolus cerebralis to the actinosporean stage in Tubifex tubifex. Int J Parasitol 28:195-217

El-Matbouli M, Hoffmann RW (2002) Influence of water quality on the outbreak of proliferative kidney disease: field studies and exposure experiments. J Fish Dis 25:459-467

> El-Matbouli M, McDowell TS, Antonio DB, Andree KB, Hedrick RP (1999) Effect of water temperature on the development, release and survival of the triactinomyxon stage of Myxobolus cerebralis in its oligochaete host. Int J Parasitol 29:627-641

Gilbert MA, Granath WO (2001) Persistent infection of Myxobolus cerebralis, the causative agent of salmonid whirling disease, in Tubifex tubifex. J Parasitol 87:101-107

Gillis PL, Diener LC, Reynoldson TB, Dixon DG (2002) Cadmium-induced production of a metallothioneinlike protein in Tubifex tubifex (Oligochaeta) and Chironomus riparius (Diptera): correlation with reproduction and growth. Environ Toxicol Chem 21:1836-1844

Hallett SL, Bartholomew JL (2008) Effects of water flow on the infection dynamics of Myxobolus cerebralis. Parasitology 135:371-384

> Hoole D (1997) The effects of pollutants on the immune response of fish: implications for helminth parasites. Parassitologia 39:219-225

Jirsa F, Leodolter-Dvorak M, Krachler R, Frank C (2008) Heavy metals in the nase, Chondrostoma nasus (L. 1758), and its intestinal parasite Caryophyllaeus laticeps (Pallas, 1781) from Austrian rivers: bioindicative aspects. Arch Environ Contam Toxicol 55:619-626

Kerans BL, Zale AV (2002) The ecology of Myxobolus cerebralis. In: Bartholomew JL, Wilson JC (eds) Whirling disease: reviews and current topics. Am Fish Soc Symp 29: 145-166

Kerans BL, Rasmussen C, Stevens R, Colwell AEL, Winton JR (2004) Differential propagation of the metazoan parasite Myxobolus cerebralis by Limnodrilus hoffmeisteri, Ilyodrilus templetoni, and genetically distinct strains of Tubifex tubifex. J Parasitol 90:1366-1373

Khan RA (2003) Health of flatfish from localities in Placentia Bay, Newfoundland, contaminated with petroleum and PCBs. Arch Environ Contam Toxicol 44:485-492

Khan RA, Thulin J (1991) Influence of pollution on parasites of aquatic animals. Adv Parasitol 30:201-238

Lafferty KD (2008) Ecosystem consequences of fish parasites. J Fish Biol 73:2083-2093

Lom J, Dykova I (2006) Myxozoan genera: definition and notes on taxonomy, life-cycle terminology and pathogenic species. Folia Parasitol 53:1-36
Lucan-Bouché ML, Risbourg SB, Arsac F, Vernet G (1999) An original decontamination process developed by the aquatic oligochaete Tubifex tubifex exposed to copper and lead. Aquat Toxicol 45:9-17

> MacKenzie K (1999) Parasites as pollution indicators in marine ecosystems: a proposed early warning system. Mar Pollut Bull 38:955-959

MacKenzie K, Williams HH, Williams B, McVicar AH, Siddal R (1995) Parasites as indicators of water quality and the potential use of helminth transmission in marine pollution studies. Adv Parasitol 35:85-144

- Marcogliese DJ (2005) Parasites of the superorganism: Are they indicators of ecosystem health? Int J Parasitol 35: 705-716

Marcogliese DJ, Cone DK (1997) Parasite communities as indicators of ecosystem stress. Parassitologia 39:227-232

Markiw ME, Wolf K (1983) Myxosoma cerebralis (Myxozoa, Myxosporea) etiologic agent of salmonid whirling disease requires tubificid worm (Annelida, Oligochaeta) in its lifecycle. J Protozool 30:561-564

- Milani D, Reynoldson TB, Borgmann U, Kolasa J (2003) The relative sensitivity of four benthic invertebrates to metals in spiked-sediment exposures and application to contaminated field sediment. Environ Toxicol Chem 22:845-854

- Modin J (1998) Whirling disease in California: a review of its history, distribution, and impacts, 1965-1997. J Aquat Anim Health 10:132-142

> Morley NJ, Crane M, Lewis JW (2004) Influence of cadmium exposure on the incidence of first intermediate host encystment by Echinoparyphium recurvatum cercariae in Lymnaea peregra. J Helminthol 78:329-332

Nehring RB, Walker PG (1996) Whirling disease in the wild: the new reality in the intermountain West. Fisheries 21: $28-30$

Patz JA, Graczyk TK, Geller N, Vittor AY (2000) Effects of environmental change on emerging parasitic diseases. Int J Parasitol 30:1395-1405

Perez-Del-Olmo A, Montero FE, Raga JA, Fernandez M, Kostadinova A (2009) Follow-up trends of parasite community alteration in a marine fish after the Prestige oilspill: Shifting baselines? Environ Pollut 157:221-228

Poulin R (1992) Toxic pollution and parasitism in freshwater fish. Parasitol Today 8:58-61

Prunescu CC, Prunescu P, Pucek Z, Lom J (2007) The first finding of myxosporean development from plasmodia to spores in terrestrial mammals: Soricimyxum fegati gen. et sp n. (Myxozoa) from Sorex araneus (Soricomorpha). Folia Parasitol 54:159-164

Rasmussen C, Zickovich J, Winton JR, Kerans BL (2008) Variability in triactinomyxon production from Tubifex tubifex populations from the same mitochondrial DNA lineage infected with Myxobolus cerebralis, the causative agent of whirling disease in salmonids. J Parasitol 94:700-708

Sanchez-Ramirez C, Vidal-Martinez VM, Aguirre-Macedo ML, Rodriguez-Canul RP, Gold-Bouchot G, Sures B (2007) Cichlidogyrus sclerosus (Monogenea: Ancyrocephalinae) and its host the Nile tilapia (Oreochromis niloticus) as bioindicators of chemical pollution. J Parasitol 93: 1097-1106

Shirakashi S, El-Matbouli M (2009) Myxobolus cerebralis (Myxozoa), the causative agent of whirling disease, reduces fecundity and feeding activity of Tubifex tubifex (Oligochaeta). Parasitology 136:603-613

> Steinbach Elwell LC, Kerans BL, Rasmussen C, Winton JR (2006) Interactions among two strains of Tubifex tubifex (Oligochaeta: Tubificidae) and Myxobolus cerebralis (Myxozoa). Dis Aquat Org 68:131-139 
Stevens R, Kerans BL, Lemmon JC, Rasmussen C (2001) The effects of Myxobolus cerebralis myxospore dose on triactinomyxon production and biology of Tubifex tubifex from two geographic regions. J Parasitol 87:315-321

Sturmbauer C, Opadiya GB, Niederstatter H, Riedmann A, Dallinger R (1999) Mitochondrial DNA reveals cryptic oligochaete species differing in cadmium resistance. Mol Biol Evol 16:967-974

Sures B (2008) Host-parasite interactions in polluted environments. J Fish Biol 73:2133-2142

Valtonen ET, Holmes JC, Koskivaara M (1997) Eutrophication, pollution and fragmentation: effects on parasite communities in roach (Rutilus rutilus) and perch (Perca fluviatilis) in four lakes in central Finland. Can J Fish Aquat Sci 54:572-585

Wieczorek-Olchawa E, Niklinska M, Miedzobrodzki J, Ply-

Editorial responsibility: Dieter Steinhagen,

Hannover, Germany tycz B (2003) Effects of temperature and soil pollution on the presence of bacteria, coelomocytes and brown bodies in coelomic fluid of Dendrobaena veneta. Pedobiologia 47: 702-709

Williams HH, MacKenzie K (2003) Marine parasites as pollution indicators: an update. Parasitology 126:S27-S41

Witeska M, Wakulska M (2007) The effects of metals on common carp white blood cells in vitro. Altern Lab Anim 35: $87-92$

Witeska M, Jezierska B, Wolnicki J (2006) Respiratory and hematological response of tench, Tinca tinca (L.) to a short-term cadmium exposure. Aquac Int 14:141-152

> Wolf K, Markiw ME, Hiltunen JK (1986) Salmonid whirling disease: Tubifex tubifex (Müller) identified as the essential oligochaete in the protozoan life cycle. J Fish Dis 9: $83-85$

Submitted: July 7, 2009; Accepted: November 2, 2009 Proofs received from author(s): February 9, 2010 